Contributions:

A Study design/planning

B Data collection/entry

C Data analysis/statistics

D Data interpretation

E Preparation of manuscript

F Literature analysis/search

$\mathrm{G}$ Funds collection

\title{
HEARING LOSS DUE TO OSTEOGENESIS IMPERFECTA IN TWO CHILDREN
}

\author{
Henryk Skarżyński ${ }^{1 \mathrm{ADE}}$, Kamila Kordowska ${ }^{1 \mathrm{BCEF}}$, Piotr H. Skarżyński 1,2,3ADE \\ ${ }^{1}$ Department of Otolaryngology, World Hearing Centre, Institute of Physiology and \\ Pathology of Hearing Warsaw/Kajetany, Mochnackiego 10, 02-042 Warsaw, Poland \\ 2 Department of Heart Failure and Cardiac Rehabilitation, Medical University of Warsaw, \\ Kondratowicza 8, 03-242 Warsaw, Poland \\ ${ }^{3}$ Institute of Sensory Organs, Kajetany, Mokra 1, 05-830 Nadarzyn, Poland
}

Corresponding author: Kamila Kordowska M.D. Department of Otolaryngology, World Hearing Centre, Institute of Physiology and Pathology of Hearing Warsaw/ Kajetany, Mochnackiego 10, 02-042 Warsaw, Poland, e-mail: osinska.kam@gmail.com, Tel. +48793736258

\section{Abstract}

Hearing loss in osteogenesis imperfecta (OI) typically begins in the third decade of life. OI rarely occurs in childhood. Case reports of hearing loss in pediatric patients with OI are considered as merely incidental, and until now pediatric OI cases have not been presented in the literature. Typically, hearing loss is conductive, but over time a sensorineural component also occurs. There are some reports of profound sensorineural hearing loss, but this type of loss is believed to be due to additional genetic factors. The two case reports described in this paper show how the hearing loss due to OI can be treated by means of stapedotomy and restapedotomy.

Key words: Osteogenesis imperfecta $\bullet$ stapedotomy $\bullet$ conductive hearing loss $\bullet$ mixed hearing loss $\bullet$ child

\section{PÉRDIDA AUDITIVA DEBIDO A OSTEOGÉNESIS IMPERFECTA EN LA POBLACIÓN PEDIÁTRICA}

Resumen

La pérdida de audición en la osteogénesis imperfecta (OI) ocurre típicamente en la tercera década de la vida. La OI raramente vez tiene un comienzo en la infancia.

Los casos declarados de pérdida auditiva en pacientes pediátricos con OI se consideran meramente incidentales y hasta ahora no se han presentado casos pediátricos de OI en la literatura. Tipicamente, al inicio la pérdida auditiva es conductiva pero, a lo largo de los años, aparece también un componente neurosensorial. Se encuentran disponibles informes de pérdida auditiva profunda en niños; sin embargo, se cree que este tipo de pérdida de audición es el resultado de una predisposición genética adicional. Las descripciones de los casos clínicos contenidas en este artículo presentan el tratamiento de la pérdida auditiva mediante estapedotomía y restapedotomía. Además, presentan los resultados auditivos de estas operaciones, que no han sido reportados en la literatura hasta el momento.

Palabras clave: osteogénesis imperfecta $\bullet$ estapedotomía $\bullet$ pérdida auditiva conductiva $\bullet$ pérdida auditiva mixta $\bullet$ niño

\section{ТУГОУХОСТЬ ПРИ НЕСОВЕРШЕННОМ ОСТЕОГЕНЕЗЕ В ПЕДИАТРИЧЕСКОЙ поПуляцИи}

\begin{abstract}
Аннотация
Тугоухость при несовершенном остеогенезе обычно появляется в возрасте около 30 лет. Она редко развивается в детском возрасте. Описания лечения тугоухости у детей с несовершенным остеогенезом являются крайне эпизодическими. Как правило, первой появляется кондуктивная тугоухость, а с годами добавляется сенсоневральный компонент. Существуют описания глубокой нейросенсорной тугоухости у детей. Однако, считается, что данный тип тугоухости является результатом дополнительных генетических мутаций. Описания клинических случаев, содержащиеся в этой статье, представляют лечение тугоухости с помощью стапедопластики и повторной стапедопластики. Кроме того, они описывают результаты обследований слуха после подобных операций, о которых до сих пор не сообщалось в литературе.
\end{abstract}

Ключевые слова: несовершенный остеогенез • стапедопластика • кондуктивная тугоухость • тугоухость смешанного типа • ребенок 


\section{NIEDOSŁUCH W OSTEOGENESIS IMPERFECTA W POPULACJI PEDIATRYCZNEJ}

\section{Streszczenie}

Niedosłuch w Osteogenesis imperfecta typowo pojawia się w 3 dekadzie życia. Bardzo rzadko ma początek w dzieciństwie. Opisy przypadków leczenia niedosłuchu u dzieci z Osteogenesis imperfecta są kazuistyczne. Typowo, jako pierwszy pojawia się niedosłuch przewodzeniowy, a z biegiem lat pojawia się komponenta odbiorcza. Dostępne są opisy głębokiego niedosłuchu odbiorczego u dzieci. Aczkolwiek uważa się, że ten typ niedosłuchu jest skutkiem dodatkowych mutacji genetycznych. Opisy przypadków kliniczych zawarte w tej pracy przedstawiają leczenie niedosłuchu za pomocą stapedotomii i restapedotomii. Dodatkowo przedstawiają wyniki słuchowe tych operacji co dotychczas nie było raportowane $\mathrm{w}$ literaturze.

Słowa kluczowe: Osteogenesis imperfecta $\bullet$ stapedotomia $\bullet$ niedosłuch przewodzeniowy $\bullet$ niedosłuch mieszany $\bullet$ dziecko

\section{Introduction}

Osteogenesis imperfecta (OI) is a genetically determined connective tissue disorder which manifests within systems and organs with a high collagen content. It is characterised by recurrent bone fractures (leading to skeletal deformities), blue sclerae, and dentinogenesis, as well as excessive skin and joint laxity, short stature, and hearing loss [1]. The onset of hearing loss is typically seen in the third decade of life [2,3]; however, paediatric cases have also been reported [4,5]. A study by Kuurila et al. [5] showed that in a group of paediatric patients with OI, conductive hearing loss affected $4.4 \%$ of the subjects and sensorineural hearing loss $2.2 \%$. In the available reports of hearing loss in children, the youngest patient was 11 years old and had moderate conductive hearing loss with air conduction thresholds of $40 \mathrm{~dB}$ [5]. Typically, hearing loss is initially conductive, with the sensorineural component occurring over time $[2,3]$. The symptoms within the middle ear are caused by ossicular chain defects, most frequently of the stapes (i.e. thickened stapes footplate, obliteration of the stapes, fracture of the stapes crura), as well as their excessive laxity or discontinuity [6-8] - at this point the conductive component appears. Consequently, it is possible that middle ear surgery may be effective for children with OI. However, the available literature on middle ear surgery for OI in children is limited; the purpose of this study is to present two case studies of middle ear surgery with children experiencing OI.

\section{Material and method}

This publication is based on approval by the Bioethics Committee of the Institute of Physiology and Pathology of Hearing (IFPS: KB/14/2016). This approval is consistent with the Code of Ethics of the World Medical Association. Informed consent was not necessary due to the retrospective nature of the study.

The first case study refers to a 17-year-old female patient who had suffered hearing disturbances since the age of 13 . The patient was diagnosed with OI in view of her history
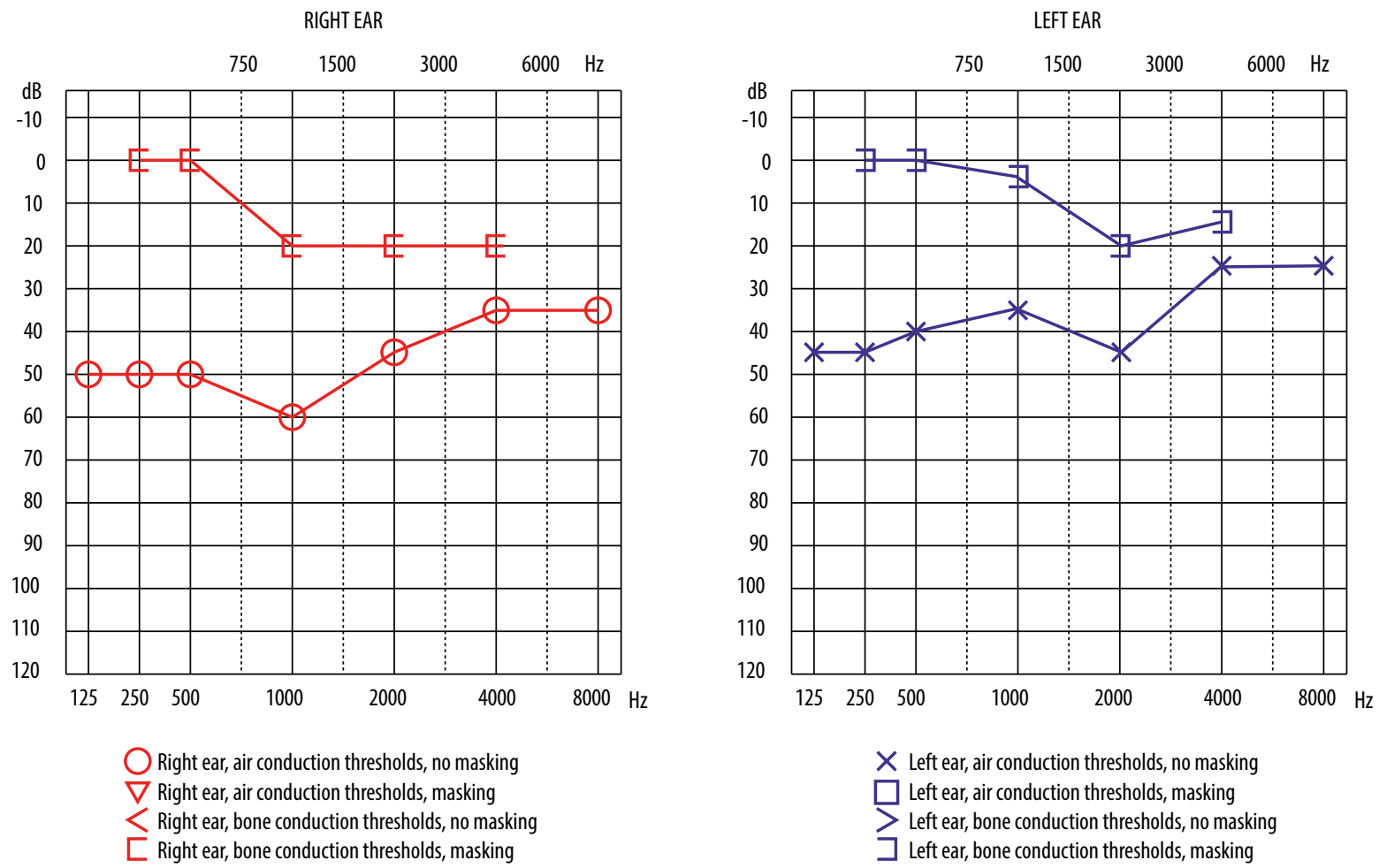

Figure 1. Pure tone audiometry prior to surgical treatment in patient I 
of recurrent bone fractures - 10 episodes of fractures of the upper and lower limbs in childhood. Other features included blue sclerae as well as a positive family history of OI, with similar manifestations reported in the patient's father, grandmother, and great-grandfather. Other signs included short stature $(160 \mathrm{~cm})$, as well as excessive laxity of the skin and joints. Basing on these phenotypic traits she was classified to type I of OI according to Sillence [9]. A physical examination revealed maintained and transparent tympanic membranes. Between the age of 14 and 17, the patient had significant progression of hearing loss. The current auditory test showed bilateral conductive hearing loss (Figure 1), type A tympanograms, and the absence of acoustic reflexes bilaterally.

The patient was qualified for exploratory tympanotomy with possible stapedotomy or ossiculoplasty of the right ear.

Surgery performed under a microscope revealed a massive bone overhang in the vicinity of the stapes footplate, with a thickened footplate of the stapes of approximately $2 \mathrm{~mm}$. A standard stapedotomy was performed with a diamond burr, followed by typical placement of a Kurz Skarżyński piston prosthesis of $0.5 \times 4.75 \mathrm{~mm}$, which was subsequently sealed with a blood clot.

The patient reported significant improvement in hearing immediately following surgery. After 5 months, i.e. at the age of 18 , the patient underwent a surgical procedure involving the left ear. As in the case of the right ear, the procedure showed a thickened and immobilised stapes footplate which was mobilised during the removal of the superstructure. An opening was subsequently made at the border of the left middle ear footplate and the promontory, followed by placement of another Kurz Skarżyński piston prosthesis, again sealed with a blood clot. During the entire procedure severe bleeding from the lining of the tympanic cavity and the bone of the external auditory canal was observed.
The second case study involved the retrospective analysis of the results of treating a 26-year-old male who had suffered hearing loss since the age of approximately $9-10$ years. The patient was diagnosed with OI during adolescence on the basis of the following manifestations: blue sclerae, 13 episodes of upper and lower limbs fractures in early childhood, rickets, dentinogenesis, and family history of OI - in the mother and grandmother on his mother's side. He was also classified as OI type I according to Sillence based on phenotypic traits [9]. Otoscopic examination revealed maintained and opaque tympanic membranes. Auditory testing showed bilateral mixed hearing loss (Figure 2), type A tympanograms, and absence of acoustic reflexes bilaterally.

The patient was qualified for exploratory tympanotomy with possible stapedotomy or ossiculoplasty of the left ear. The first surgical procedure had been carried out at the age of 14 and revealed disarticulation between the stapes superstructure, the stapes footplate, and the long process of the incus. Due to severe bleeding from the thickened lining of the tympanic cavity and walls of the auditory canal, a decision was made to carry out the procedure in two stages. Standard stapedotomy of the left ear was conducted after 1 month, with implantation of a Mikołów III BO Teflon piston prosthesis. The patient reported significant hearing improvement immediately following the procedure. After 10 months, the patient underwent exploratory tympanotomy with stapedotomy of the right ear which revealed immobilisation of the stapes and severe bleeding from the lining of the tympanic cavity. Another Mikołów III BO Teflon piston prosthesis was inserted. Hearing improvement was observed. After approximately 3 years, the patient reported a gradual progression of hearing loss in the right ear. Due to decreased auditory thresholds, he underwent restapedotomy in this ear. The procedure revealed displacement of the prosthesis from the opening in the vestibule, and the
RIGHTEAR

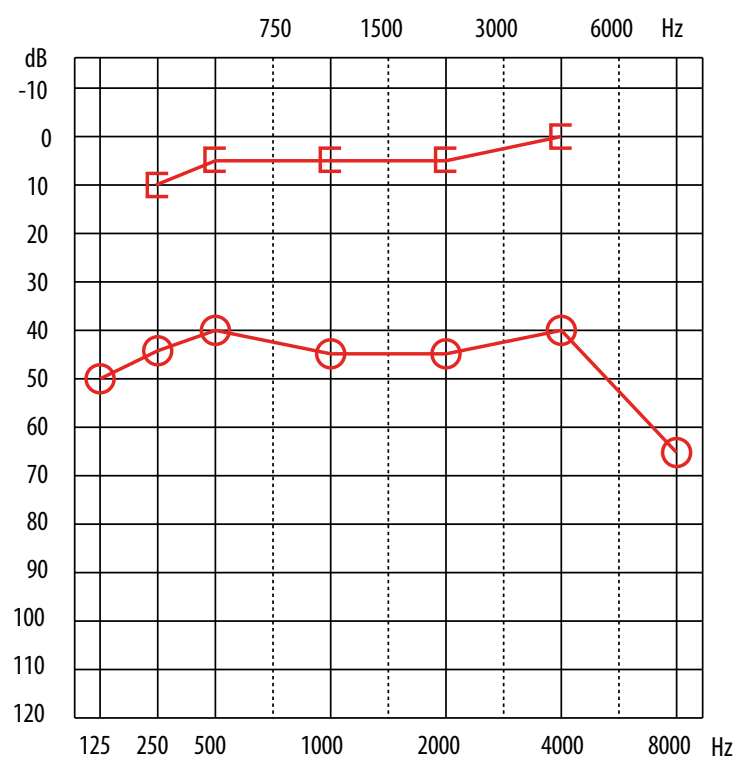

LEFT EAR

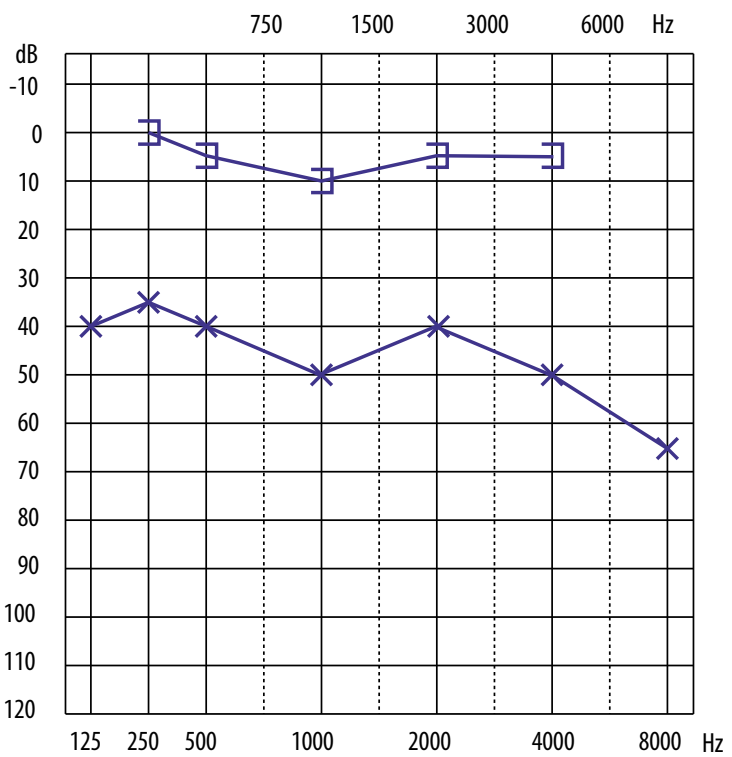

Figure 2. Pure tone audiometry prior to surgical treatment in patient II (key as per Figure 1) 
opening was covered with osseous tissue. A restapedotomy became necessary 2 years after the initial surgery and then again at 5 years in the right ear. The improvement in hearing sensitivity following the final surgery has been stable for more than 4 years (Figure 4 ).

\section{Results}

Patient 1 displayed significant decrease in the air-bone gap by $14 \mathrm{~dB}$ on average bilaterally; specifically, hearing thresholds improved by an average of $19 \mathrm{~dB}$ in the right ear and $12.5 \mathrm{~dB}$ in the left (Figure 3). Less improvement in the left ear is not unusual considering that at baseline there was a lower degree of hearing loss in the left ear.

In the case of patient II, closure of the air-bone gap was obtained after a two-stage surgery of the left ear and four surgical procedures of the right ear. Hearing thresholds observed 38 months following the last surgical procedure of the right ear are presented below (Figure 4).
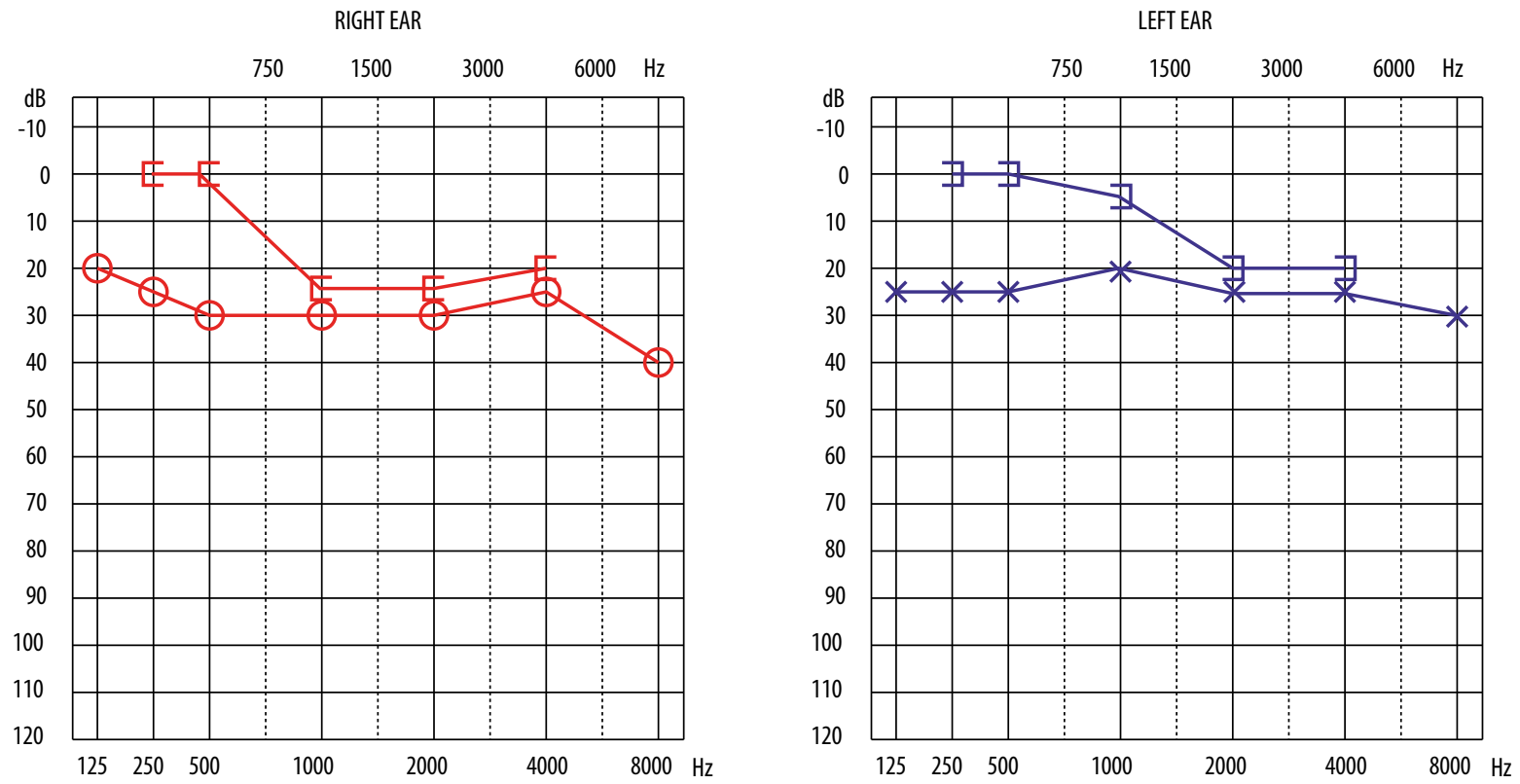

Figure 3. Tonal audiometry after surgical treatment of both ears in patient I - some 3 months following the procedure involving the left ear (key as per Figure 1)
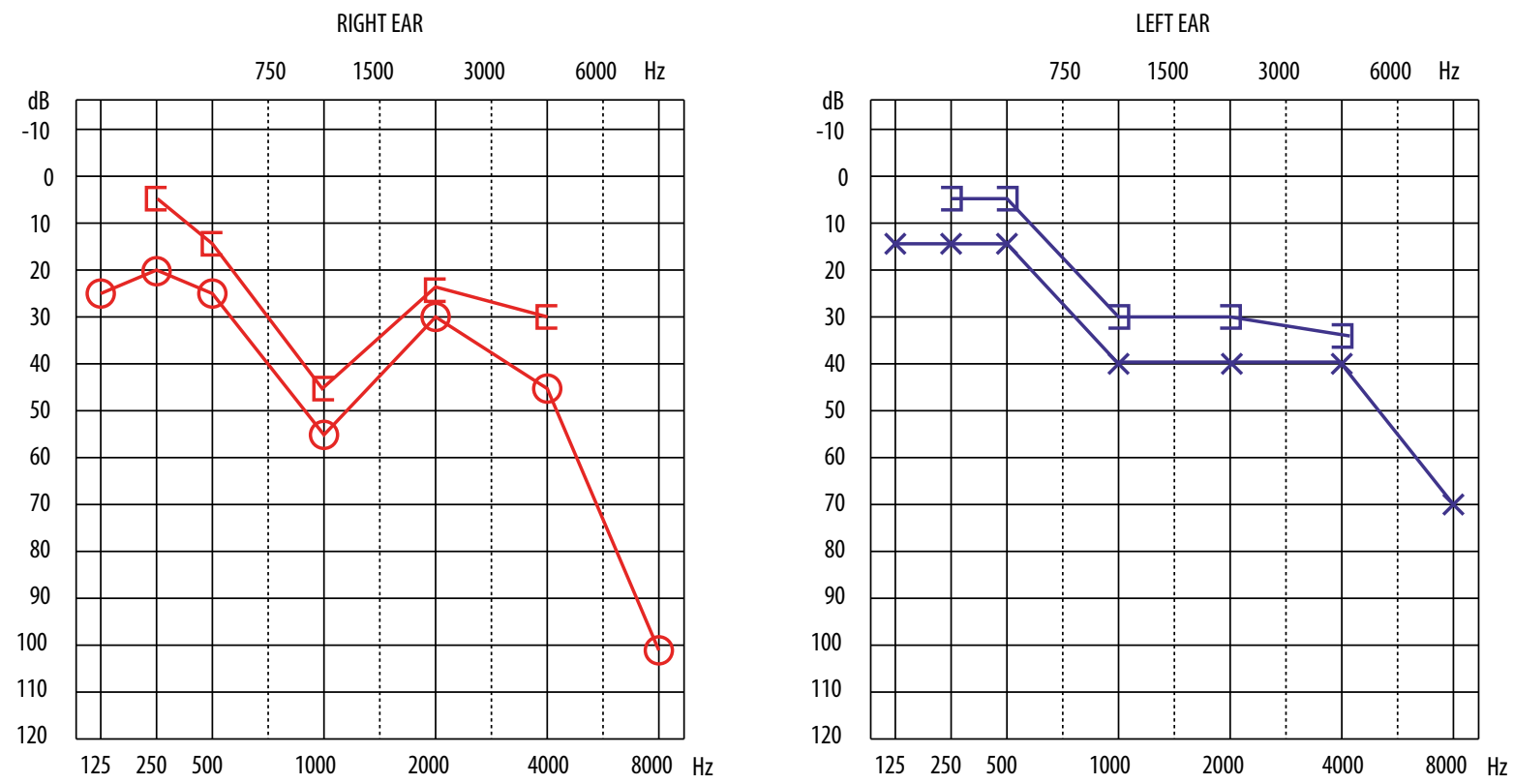

Figure 4. Tonal audiometry after surgical treatment of both ears in patient II - some 38 months following the procedure involving the right ear (key as per Figure 1) 


\section{Discussion}

The available literature reports single cases of hearing loss in children with osteogenesis imperfecta [4,5], mainly dealing with descriptions of pathologies and the diagnostic procedures used [4]. For example, Mnari and colleagues [4] considers pediatric OI cases where hearing losses are subject to a wide range of diagnostic procedures, including audiometric, genetic, and radiological examinations. Nevertheless, in general the descriptions of the surgical treatments used and the outcomes are scant. Denoyelle et al. presents results of stapes surgery on children and adolescents [10]; however in this work only one child suffered from osteogenesis imperfecta, with the others having stapes congenital fixation, juvenile otosclerosis, and posttraumatic stapes luxation. The hearing results were presented all together, with the results of the osteogenesis imperfecta subject not separately reported.

In the case of our first patient, the results of the surgical treatment were comparable to outcomes of the treatment of adult patients carried out at other centres [2,3]. The improved auditory thresholds observed in the right ear $(19 \mathrm{~dB})$ demonstrated that the procedure was effective. Even in the case of the left ear where the hearing loss was lower at baseline, auditory thresholds improved by more than $10 \mathrm{~dB}$.

In the case of the second patient, the intraoperative changes that were seen in the left ear were typical for OI: superstructure lying freely in the niche of the oval window as well as a thickened lining of the tympanic cavity. The course of hearing loss in the right ear was suggestive of ongoing bony regrowth within the ear, also typical of OI. Since the last surgery involving the right ear the patient's condition has been stable for 38 months. Compared to preoperative levels, the last surgical procedure led to a decrease in the air-bone gap by $39 \mathrm{~dB}$ on average; auditory thresholds also improved by the same amount. Importantly, despite the successful outcomes of surgeries in subject II, and great patient satisfaction, we did observe a minor deterioration of bone conduction thresholds. The deterioration can be connected to advanced changes in the middle ear, typical of OI patients, and due to the fact that the surgery was more risky. Bony growth in the cochlear duct can also be a factor in deterioration of bone conduction thresholds. In this patient we noted regrowth in the oval window niche, which was the reason for the restapedotomy, so we believe that bone remodeling was active and could have impacted bone conduction thresholds. Nevertheless, subject II considered the final hearing levels were satisfactory.

\section{Conclusion}

Hearing loss in the course of OI is rarely observed in children. Case studies of otosurgical treatment and its outcomes are deemed to be merely incidental. The changed bone anatomy and structure increase the risk of the procedure, thus making it the decisive factor in the choice of a conservative method of treatment - hearing aids - at many centres. Nevertheless, surgical treatment conducted by an experienced otosurgeon can allow significant improvement of hearing to be achieved even in young OI patients.

\section{Disclosure statement}

All the authors confirm that there are no known conflicts of interest associated with this publication and there has been no significant financial support for this work that could have influenced its outcome.

\section{References}

1. F.S. Van Dijk, D.O. Sillence. Osteogenesis imperfecta: clinical diagnosis, nomenclature and severity assessment. Am J Med Genet $A, 2014 ; 164(6)$ : 1470-81

2. F.K. Swinnen, E.M. De Leenheer, P.J. Coucke, C.W. Cremers, I.J. Dhooge. Audiometric, surgical, and genetic findings in 15 ears of patients with osteogenesis imperfecta. Laryngoscope, 2009; 119(6):1171-9.

3. K. Kuurila, I. Kaitila, R. Johansson,R. Grénman. Hearing loss in Finnish adults with osteogenesis imperfecta: a nationwide survey. Ann Otol Rhinol Laryngol, 2002; 111(10): 939-46.

4. W. Mnari, C. Hafsa, R. Salem, M. Maatouk, M. Golli. Osteogenesis imperfecta and hearing loss in childhood. Arch Pediatr, 2008; 15(11): 1663-6.

5. K. Kuurila, R. Grénman, R. Johansson, I. Kaitila. Hearing loss in children with osteogenesis imperfecta. Eur J Pediatr, 2000; 159(7): $515-9$.
6. F. Santos, A. McCall, W. Chien, S.N. Merchant. Otopathology in osteogenesis imperfecta. Otol Neurotol, 2012; 33(9): 1562-6.

7. G. Berger, M. Hawke, A. Johnson, D. Proops. Histopathology of the temporal bone in osteogenesis imperfecta congenita: a report of 5 cases. Laryngoscope, 1985; 95(2): 193-199.

8. K. Osińska, P.H. Skarzynski. Hearing loss treatment in osteogenesis imperfecta: literature review. Now Audiofonol, 2017; 6(3): 9-15.

9. D. Sillence, A. Senn, D. Danks. Genetic heterogeneity in osteogenesis imperfecta. J Med Genet, 1979; 16: 101-16.

10 F. Denoyelle, M. Daval, N. Leboulanger, et al. Stapedectomy in children: causes and surgical results in 35 cases. Arch Otolaryngol Head Neck Surg, 2010; 136(10): 1005-8. 